\title{
Clipping of Water-stressed Blue Grama Affects Proline Accumulation and Productivity
}

KARIN WISIOL

\begin{abstract}
Water-stressed plants accumulate abnormally large amounts of free proline, a protein component. Blue grama (Bouteloua gracilis) was clipped and water-stressed to test whether the degree of proline accumulation might be related to regrowth potential of range grass. Clipping of plants before stress reduced the accumulation of proline in bases of stressed shoots but increased herbage production; clipping after stress speeded the decrease of accumulated proline in shoot bases.
\end{abstract}

Accumulation of free proline, to levels 100 or more times normal, has been demonstrated in many species of waterstressed plants (Hsiao 1973). Accumulation also occurs in vernalized plants (Shiomi and Hori 1973) and in halophytes, plants of salty soils (Stewart and Lee 1974). Proline, a protein component, is classed with the common amino acids (though technically an imino acid). It is closely linked to new growth through its role as precursor of hydroxyproline, essential for cell-wall protein (Fowden 1973), and can be used for respiration if carbohydrates are lacking (Stewart 1972a, 1972b).

The significance of proline accumulation, which is due to de novo synthesis (Stewart 1972a), is unknown. Stewart and Lee (1974) suggested that some halophytes use proline as a solute molecule to make osmotic adjustments within the cell. Barnett and Naylor (1966) suggested that water-stressed plants use proline as storage for carbon and nitrogen. Singh et al. (1972) found that the degree of proline accumulation in water-stressed barley corresponded to varietal drought resistance.

\section{Materials and Methods}

To test whether degree of proline accumulation might be used to indicate regrowth potential of range grass, proline concentration and productivity were measured in blue grama, Bouteloua gracilis (H.B.K.) Lag. ex Steud., noted for its tolerance of both drought and grazing (Hyder et al. 1975). Eight-month-old plants grown from Lovington-variety seed from New Mexico were subjected to water stress, clipping, or both in two growth chamber experiments.

Plants were grown in pots in a 2:1 soil:sand mixture with a 16-hour, $26^{\circ} \mathrm{C}$ day and $20^{\circ} \mathrm{C}$ night. Mature plants were given a 16 -hour, $29^{\circ} \mathrm{C}$ day and a $24^{\circ} \mathrm{C}$ night with a half-hour light break to ensure short nights. (Lavin [1953] found that southern strains of blue grama

\footnotetext{
The author is a graduate student, Department of Biological Sciences, University of Illinois at Chicago Circle, Box 4348. Chicago, III. 60680.

The author thanks Drs. J. Lussenhop, D.B. Mertz, L. Anderson, M.L. Gassman, D.N. Hyder, and I.S. Boyer for suggestions and encouragement and the University of Illinois at Chicago Circle for facilities and supplies. Pilot stock, seeds, and background information were supplied by L. Windle of the U.S.D.A. Soil Conservation Service's Plant Materials Center and J.E. Anderson of the cooperating New Mexico State University Experiment Station at Los Lunas.

Manuscript received March 29, 1978
}

remained vegetative on short nights.) Plants remained vegetative in appearance, lacking culms, under these conditions.

The sample unit was a single shoot from a tillering crown. A duplicate crown in each pot allowed for destructive sampling, e.g. of initial dry weight. Shoots to be sampled were tagged at the 4-leaf stage of development, a stage important to productivity (Sims et al. 1973).

In the first experiment, involving 96 plants, responses to watering were compared for four groups of plants differing in water stress history and clipping history. One group had been stressed before watering, one clipped before watering, one both stressed and clipped, and one neither stressed nor clipped. Responses to adequate watering over 10 days were compared; some plants from each group were sampled after 1 day, others after 10 days.

Water stress was imposed in this first experiment by withholding soil water for 4 days, when leaf water potentials had droppd to -45 bars as measured with a pressure chamber of the type described by Boyer (1967); potentials above -15 bars constituted lack of stress. These levels, set from growth chamber pilot tests, fall within responses of blue grama to field conditions (Hutcheson 1972). Clipping was done at the start of the 10-day watering regime. Clipping level of $4 \mathrm{~cm}$ defined base and top of shoot.

In a second experiment, involving 30 plants, responses to water stress of three groups of plants were compared. One group had been clipped twice-10 days before stress and at start of stress; one group had been clipped once-10 days before stress; and one group had never been clipped. Plants were subjected to increasing water stress by withholding water for 8 days, when leaf water potentials dropped to a -45 bars or less. Plants were sampled at the start and end of stress

Productivity was determined only for shoot tops (shoot material above $4 \mathrm{~cm}$ ). Proline was determined for shoot bases (lower $4 \mathrm{~cm}$ of shoot), since pilot tests indicated that most of the proline accumulated in the base. The lower $4 \mathrm{~cm}$ of the shoot was clipped into boiling $80 \%$ $(\mathrm{v} / \mathrm{v})$ ethanol, stored at $-14^{\circ} \mathrm{C}$, and later homogenized and filtered. Proline content was estimated by the colorimetric method of Chinard (1952), in which absorbance of the proline-ninhydrin product at 515 $\mathrm{nm}$ is determined. Dry weights of bases and tops were determined after drying for 1 hour at $105^{\circ} \mathrm{C}$ and 12 hours at $70^{\circ} \mathrm{C}$. Experimental conditions and methods are detailed further by Wisiol (1976).

\section{Results and Discussion}

Results of the first experiment (Table 1) show that water stress increased proline concentration in shoot bases some 90-fold over controls, from 0.03 to $2.70 \mu \mathrm{g}$ proline/mg dry weight of base. Clipping affected proline concentration only in plants also water-stressed; clipping at the end of stress speeded the decrease of accumulation proline within one day of rewatering $(P<.025)$. Dry weight variability of shoot tops was so great that a possible positive effect of clipping on productivity over 10 days could not be demonstrated statistically. 
Table 1. Changes in proline concentration ( $\mu$ g proline/mg dry weight) and in dry weight $(\mathrm{mg})$ during 10 days of adequate watering of plants previously stressed, clipped, both stressed and clipped, or neither stressed nor clipped.

\begin{tabular}{|c|c|c|c|c|}
\hline \multirow{2}{*}{ Treatment $^{1}$} & \multicolumn{3}{|c|}{$\begin{array}{l}\text { Proline concentration } \\
\text { in shoot base }\end{array}$} & \multirow{2}{*}{$\begin{array}{l}\text { Change in dry } \\
\text { weight of top } \\
\text { during } 10 \text { days }\end{array}$} \\
\hline & Start & 1 day & 10 days & \\
\hline Stressed & $2.70 \mathrm{a}$ & $0.78 \mathrm{a}$ & $0.06 \mathrm{c}$ & $0.8 \pm 12.7$ \\
\hline Clipped & $(0.03 c)$ & $0.03 \mathrm{c}$ & $0.03 \mathrm{c}$ & $8.8 \pm 14.7$ \\
\hline Stressed and clipped & (2.70a) & $0.40 \mathrm{~b}$ & $0.08 \mathrm{bc}$ & $15.9 \pm 11.9$ \\
\hline Control & $0.03 c$ & $0.06 \mathrm{c}$ & $0.01 \mathrm{c}$ & $-13.7 \pm 11.6$ \\
\hline
\end{tabular}

' Clipped groups were clipped just prior to start of watering. At that time water-stressed plants had been stressed for 4 days, during which leaf water potentials decreased to -45 bars. Clipping level of $4 \mathrm{~cm}$ defined base and top. Duplicate tagged shoots were used to derive base weights and intial top weights for unclipped groups. Replicates total 93, with uneven replication over the 10 groups sampled. Initial proline values are for two groups only: stressed and control.

-Values are raw means. Data were transformed logarithmically before analysis to stabilize variances. Transformed means of values followed by the same letter did not differ at the $P<.05$ level (orthogonal contrasts and Scheff contrasts; Brownlee 1965).

Means and standard errors of the mean are given. Differences are not significant at the $P<.05$ level.

Results of the second experiment (Table 2) show that clipping twice before water stress depressed proline accumulation in shoot bases. Proline rose 120-fold in unclipped plants under stress, to $4.0 \mu \mathrm{g} / \mathrm{mg}$ dry weight, but rose only 35 -fold, to 1.7 $\mu \mathrm{g} / \mathrm{mg}$ dry weight, in twice-clipped plants. While unclipped plants lost $33.7 \mathrm{mg}$ dry weight in shoot tops under stress, twice-clipped plants actually gained $6.5 \mathrm{mg}$ in shoot tops.

Table 2. Changes in proline concentration ( $\mu$ g proline/mg dry weight) and in dry weight ( $\mathrm{mg}$ ) of clipped and unclipped plants after 8 days of water stress during which leaf water potentials decreased to -45 bars or less. Means \pm standard errors are given.

\begin{tabular}{|c|c|c|}
\hline Treatment ${ }^{1}$ & $\begin{array}{l}\text { Change in proline } \\
\text { concentration of } \\
\text { shoot base }\end{array}$ & $\begin{array}{l}\text { Change in dry } \\
\text { weight of top }\end{array}$ \\
\hline Unclipped & $4.0 \pm 0.5$ & $-33.7 \pm 13.8$ \\
\hline Clipped once & $2.9 \pm 0.4$ & $5.9 \pm 3.3$ \\
\hline Clipped twice & $1.7 \pm 0.3^{2}$ & $6.5 \pm 1.2^{3}$ \\
\hline
\end{tabular}

' Before stress, some plants were clipped twice (10 days earlier and at start of stress); some were clipped once ( 10 days before start of stress); and some were left unclipped. Clipping level of $4 \mathrm{~cm}$ defined base and top. The number of replicates was 10 pairs for each determination except for proline in the two clipped groups ( 9 pairs each).

"Significantly different from unclipped group $(P<0.005)$ (Scheff contrast; Brownlee 1965).

Significantly different from unclipped group $(P<0.001)\left(t^{\prime}\right.$-test, using Welch statistic, to allow for inequality for variances; Brownlee 1965).

Increased dry weight production of plants that were clipped before stress may be due to the fact that clipping of mature, rapidly transpiring tissue allows more water for use under stress by meristematic tissue in the base, which produces new growth. Loss of dry weight in shoot tops by control plants suggests that growth conditions-relatively high temperatures and long days-may have hastened senescence in unclipped plants.

The observation that clipping significantly depresses accumulation of free proline in water-stressed plants has not been reported previously. The lower proline content might be due to reduced de novo synthesis. Since proline synthesis is inhibited by proline itself in immature tissue but not wholly so in mature tissue (Oaks et al. 1970), clipping might reduce proline synthesis in the base by removing sites to which proline is normally transported from the base or by speeding creation of new tissue there.

If degree of proline accumulation under water stress is correlated with drought resistance in blue grama, then the effect of clipping on plants subsequently stressed-speeding growth while reducing proline accumulation-suggests that rapidly growing plants may be less drought resistant. This effect of clipping also suggests that agc or growth rate of stressed shoots may affect degree of proline accumulation; future attempts to correlate proline accumulation with drought resistance should take this possibility into account.

\section{Literature Cited}

Barnett, N.M., and A.W. Naylor. 1966. Amino acid and protein metabolism in Bermudagrass during water stress. Plant Physiol. 41:1222-1230.

Boyer, J.S. 1967. Leaf water potentials measured with a pressure chamber. Plant Physiol. 42:133-137.

Brownlee, K.A. 1965. Statistical Theory and Methodology in Science and Engineering. 2nd ed. New York: Wiley. 590 p.

Chinard, F.P. 1952. Photometric estimation of proline and ornithine. J. Biol. Chem. 199:91-95.

Fowden, L. 1973. Amino acids. In: Phytochemistry: Organic Metabolites, Vol. 2, ed. L.P. Miller, p. 1-29. New York: Van Nostrand.

Hsiao, T.C. 1973. Plant responses to water stress. Annu. Rev. Plant Physiol. 24:519-70.

Hutcheson, J.L. 1972. Response patterns of Bouteloua gracilis leaf water potential measured with the thermocouple psychrometer. MS Thesis, Univ. Wyoming, Laramie. $61 \mathrm{p}$.

Hyder, D.N., R.E. Bement, E.E. Remmenga, and D.F. Hervey. 1975. Ecological responses of native plants and guidelines for management of shortgrass range. U.S. Dep. Agr., Agr. Res. Serv., Tech. Bull. 1503. 87 p.

Lavin, Fred. 1953. Photoperiodic responses of geographic strains of blue grama. PhD Diss., Univ. Chicago, Chicago. 59 p.

Oaks, Ann, D.J. Mitchell, R.A. Barnard, and F.J. Johnson. 1970. The regulation of proline biosynthesis in maize roots. Can. J. Bot. 48:2249-2257.

Shiomi, N., and S. Hori. 1973. Proline- $\mathrm{C}^{14}$ metabolism in barley seedlings during vernalization. Plant Cell Physiol. 14:1009-1018.

Sims, P.L., R.K. Lang' at, and D.N. Hyder. 1973. Developmental morphology of blue grama and sand bluestem. J. Range Manage. 26:340-344.

Singh, T.N., D. Aspinall, and I..G. Paleg. 1972. Proline accumulation and varietal adaptability to drought in barley: a potential metabolic measure of drought resistance. Nature New Biol. 236:188-190.

Stewart, C.R. 1972a. Effects of proline and carbohydrates on the metabolism of exogenous proline by excised bean leaves in the dark. Plant Physiol. 50:551-555.

Stewart, C.R. 1972b. The effect of wilting on proline metabolism in excised bean leaves in the dark. Plant Physiol. 51:508-511.

Stewart, G.R., and J.A. Lee. 1974. The role of proline accumulation in halophytes. Planta 120:279-289.

Wisiol, K. 1976. Effects of water stress and clipping on proline concentration and dry weight in blue grama (Bouteloua gracilis). MS Thesis, Univ. Illinois, Chicago. 98 p. 